Received 13.01.2014 Reviewed 13.03.2014 Accepted 25.05.2014

A - study design

B - data collection

C - statistical analysis

D - data interpretation

$\mathbf{E}$ - manuscript preparation

F - literature search

\title{
The relationship between dissolved organic carbon and hydro-climatic factors in peat-muck soil
}

\author{
Jacek JASZCZYŃSKI ${ }^{\text {ABCDEF }}$
}

Institute of Technology and Life Science in Falenty, Experimental Department in Biebrza, 19-200 Grajewo, Poland; e-mail: j.jaszczynski@itp.edu.pl

For citation: Jaszczyński J. 2015. The relationship between dissolved organic carbon and hydro-climatic factors in peatmuck soil. Journal of Water and Land Development. No. 24 p. 27-33

\begin{abstract}
The object of this study was the concentration of dissolved organic carbon (DOC) in soil solution related to groundwater table, soil temperature, moisture, redox potential and intensive storm rain and their changes during ten years (2001-2010). The studies were localized in drained and agriculturally used Kuwasy Mire situated in the middle basin of the Biebrza River, north-eastern Poland. The study site was situated on a low peat soil managed as intensively used grassland. The soil was recognized as peat-muck in the second stage of the mucking process. DOC concentration was determined by means of the flow colorimetric method using the Skalar equipment.

Mean in the whole study period DOC concentration in soil solution was $72 \mathrm{mg} \cdot \mathrm{dm}^{-3}$. A significant positive correlation was observed between DOC concentration and soil temperature at $30 \mathrm{~cm}$ depth. The highest DOC concentrations were observed from July to October accompanied by the lowest ground water level. The DOC concentration in soil solution showed also a significant correlation with soil redox potential at $20 \mathrm{~cm}$ depth a border between muck and peat layers. This layer is potentially most active with respect to biochemical transformation. There was no relationship between DOC concentration and soil moisture. However, the influence of torrential rains on the intensity of DOC removal was demonstrated in this study.
\end{abstract}

Key words: $D O C$, peat-muck soils, redox potential, soil solution, soil temperature, torrential rains

\section{INTRODUCTION}

Transformed peatlands have a great influence on the organic matter load in waters of particular habitats [GÓRNIAK 1996; TIPPING et al. 1999; ZSOLNAY 1996]. The loss of organic matter in mineralization process of peat soil is connected with the release of humic substances to water. They are mainly built of carbon. High concentrations of dissolved organic carbon (DOC) are observed in ground and surface waters from peatlands. DOC is a very essential component of total carbon circulation in soil-water habitat [DAWSON et al. 2002]. The load of this type of carbon released from soil is dispersed outside mire habitats with moving water [BALLA et al. 2000; QUINBY 2000; SMAL et al. 2004].
Seasonal changes of temperature and soil moisture, magnitude of precipitations and the degree of soil draining may result in higher mineralization and higher DOC release and displacement. Soil temperature is a very important factor since it activates soil microflora during the vegetation period. These processes have also higher intensity when muck layers and layers with transformed peat are sufficiently aerated. Then, the amount of carbon compounds exposed to leaching from soil profile is bigger [JASZCZYŃSKI et al. 2008; NADANY, SAPEK 2004; OKRUSZKO, KOZAKIEWICZ 1973]. High ground water table can influence mobilization of dissolved carbon compounds that has been accumulated in the soil during the periods of much lower ground water table. Longer periods of higher DOC concentrations can also be caused by 
slow return of water to surface layers of soil profile after summer [KALBITZ et al. 2002].

The question is, how do soil-water conditions, which in some periods favour stronger mineralization of soil organic matter, affect DOC concentration in water of soil profile? Is it possible to show the influence of habitat and meteorological factors on longlasting process responsible for transport of dissolved carbon compounds to waters? Most studies described DOC in view of its concentration in surface waters (rivers, lakes) for a given catchment and very often for different types of mineral soils. Much less numerous are the papers reporting DOC concentration in soil profile, in ground water or in soil solution of drained peat soils [JASZCZYŃSKI 2011; RUPP et al. 2002; SAPEK 2007].

The main aim of this study was to present temporary changes in DOC concentration in water resources of highly transformed peat soils and to determine the influence of soil temperature, soil moisture, redox potential and torrential rains on DOC concentration in soil solution from peat-muck soil.

\section{MATERIAL AND METHODS}

The study was carried out in 2001-2010 in the Kuwasy Mire in the middle basin of the Biebrza River, north-eastern Poland [BANASZUK 2004], in the Biebrza Experimental Station, ITP Falenty (N 53.650 E 22.577). The study site borders the Biebrzański National Park. Described peatland was drained in the 1930's and 1950's and now is used as agricultural land. Meadows and pastures predominate in the landscape. They are situated on organic soils that formed from fen's peat deposits. Soil in the study site (under meadow) was recognized as peat-muck soil (WRB: Terric Histosol) in the second stage of mucking process (MtIIcb in Polish classification [OKRUSZKO, PIAŚCIK 1990]). That type of soil occupies about $56 \%$ of the study area [SzUNIEWICZ et al. 1995] and this was the reason of interest in present research work.

The depth of bog in study site was $110-120 \mathrm{~cm}$ and the main organic material consisted of forest-sedge peat: $\mathrm{Mt}-0-22 \mathrm{~cm}$; Ot $-22-110 \mathrm{~cm}$; D - below 110 $\mathrm{cm}$. Detailed characteristics of soil profile were:

0-5 cm - turf layer with grained muck $\left(\mathrm{M}_{1}\right)$,

5-17 cm - humic muck $\left(\mathrm{M}_{2}\right)$,

$17-22 \mathrm{~cm}$ - peaty muck $\left(\mathrm{M}_{3}\right)$,

22-40 cm - sedge peat $R_{3}$,

40-74 cm - willow peat $\mathrm{R}_{3}$,

$74-87 \mathrm{~cm}$ - alder swamp forest peat $R_{3} / R_{2}$,

$87-95 \mathrm{~cm}$ - sedge peat $\mathrm{R}_{2}$,

95-105 $\mathrm{cm}-$ moss peat $\mathrm{R}_{1} / \mathrm{R}_{2}$,

$105-110 \mathrm{~cm}$ - transitional layer,

$>110 \mathrm{~cm}$ - mineral substratum (medium grain loose sand).

An automatic field station was installed in the soil under mown meadow. Ceramic suction cups to collect soil solution samples were mounted in three replications at $30 \mathrm{~cm}$ depth. The soil solution was continuously sampled by a pump of the automatic station at pressure equal to $22 \cdot 10^{3} \mathrm{~Pa}$. The successive samples comprised the solution collected at the intervals of 21 days. At the same depth, temperature and soil moisture were recorded automatically as twentyfour hour mean data. Simultaneously, at the 20, 30 and $40 \mathrm{~cm}$ depth the measurements of redox potential were made. Every three days the groundwater table was noted in an additional well situated in the field station area. This well involved organic layers to 110 $\mathrm{cm}$ depth. Samples of soil solution were filtered through a $0.45 \mu \mathrm{m}$ filter. DOC concentration was determined in the laboratory of ITP Falenty by means of the flow colorimetric method using the Skalar equipment in the following main stages: 1) removing inorganic carbon; 2) oxidising organic carbon to $\mathrm{CO}_{2} ; 3$ ) measuring colour intensity at $\lambda=550 \mathrm{~nm}$ in throughflow cuvettes [Skalar 2002]. Absorbance of soil solution samples was also measured at $\lambda=280 \mathrm{~nm}$ and $\lambda=$ $472 \mathrm{~nm}$.

In 2002 soil samples were collected from layers: 5-10, 15-20, 25-30, 35-40 cm to determine the content of mineral parts, bulk density, $\mathrm{pH}$, the content of organic carbon (with the Tiurin's method modified by Orłow [SAPEK, SAPEK 1999] and DOC concentration. The last parameter was measured in water extracts from soil ( $20 \mathrm{~g}$ of soil in $100 \mathrm{~cm}^{3} \mathrm{H}_{2} \mathrm{O}$ ) using the method described above for soil solutions [Skalar 2002].

For statistical calculations, redox potential, moisture and soil temperature values were compared as means for successive time intervals which corresponded to soil solution sampling periods. DOC concentration on every sampling occasion represents mean values from three replications. The coefficients of correlation between DOC concentration in soil solution and above mentioned soil and meteorological parameters were calculated.

\section{RESULTS AND DISCUSSION}

Studied soil was acid $(\mathrm{pH}=5.5-5.7)$. As a result of mucking process, an increment in the content of mineral parts and in bulk density was observed in the upper soil layers (Tab. 1). The content of organic carbon in soil material increased with depth. On the contrary, DOC concentration (in water extract from soil) decreased with depth being nearly two times higher in turf layer than in $35-40 \mathrm{~cm}$ soil layer.

Table 1. Physical parameters of soil in studied point

\begin{tabular}{|c|c|c|c|c|c|}
\hline $\begin{array}{c}\text { Depth } \\
\mathrm{cm}\end{array}$ & $\begin{array}{c}\mathrm{pH} \\
1 \mathrm{M} \mathrm{KCl}\end{array}$ & $\begin{array}{c}\text { Content of } \\
\text { mineral } \\
\text { parts } \\
\% \mathrm{DM}\end{array}$ & $\begin{array}{c}\text { Bulk } \\
\mathrm{density} \\
\mathrm{g} \cdot \mathrm{cm}^{-3}\end{array}$ & $\begin{array}{c}\text { Corg } \\
\% \text { of } \\
\text { weight }\end{array}$ & $\begin{array}{c}\text { DOC concentra- } \\
\text { tion in water } \\
\text { extract from soil } \\
\mathrm{mg} \mathrm{C} \cdot \mathrm{dm}^{-3}\end{array}$ \\
\hline $5-10$ & 5.5 & 20 & 0.273 & 40 & 1420 \\
\hline $15-20$ & 5.5 & 15 & 0.221 & 41 & 1030 \\
\hline $25-30$ & 5.6 & 12 & 0.185 & 45 & 880 \\
\hline $35-40$ & 5.7 & 10 & 0.175 & 45 & 860 \\
\hline
\end{tabular}

Source: own study. 
Mean for the whole study period DOC concentration in soil solution was high and amounted $72 \mathrm{mg}$ $\mathrm{C} \cdot \mathrm{dm}^{-3}$. Similar methods described in this paper were applied by KALBITZ [2001], who found mean DOC concentration of $83 \mathrm{mg} \mathrm{C} \cdot \mathrm{dm}^{-3}$ in soil solution from $25 \mathrm{~cm}$ depth (relatively intact peatland with long-term extensive grassland farming - Terric Histosols). Annual mean DOC concentration in our study was increasing in the study period (Fig. 1). The highest DOC concentration was observed during the last four years and in 2010 it was more than two times higher than that in the first year of this study. Presented changes were responsible for significant deterioration of the quality of shallow ground waters which largely discharged to the ditch network draining the study object. Much longer research period is needed to ascertain whether the temporal increase in DOC concentration is a stable tendency. However, the strongest influence on described changes was exerted by transformations that occurred in soil in May, June and October (Tab. 2). The highest increment of the amount of DOC released from soil material to soil solution was determined in these months. In other months this tendency was noted but it was much weaker.

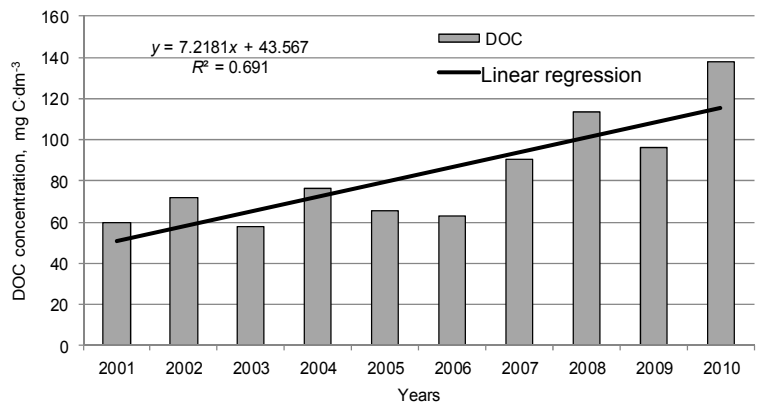

Fig. 1. Changes in the annual mean DOC concentration in soil solution from peat-muck soil $(30 \mathrm{~cm}$ depth) during the ten-year study; own study

Table 2. Values of $R^{2}$ for the trend line describing changes in DOC concentration in particular months of the years 2001-2010

\begin{tabular}{|c|c|c|c|c|c|c|c|c|c|c|c|}
\hline \multicolumn{10}{|c|}{$R^{2}$ in month } \\
\hline Jan & Feb & Mar & Apr & May & Jun & Jul & Aug & Sep & Oct & Nov & Dec \\
\hline 0,26 & 0,28 & 0,30 & 0,39 & $\mathbf{0 , 7 5}$ & $\mathbf{0 , 6 8}$ & 0,45 & 0,35 & 0,26 & $\mathbf{0 , 6 7}$ & 0,41 & 0,32 \\
\hline
\end{tabular}

Source: own study.

DOC concentration in analysed soil solution was highly differentiated during a year, however, it showed clear seasonal fluctuation. The highest mean monthly concentrations were observed from July till September (Fig. 2). In samples collected in this period, DOC concentration ranged between 120 and 150 $\mathrm{mg} \mathrm{C} \cdot \mathrm{dm}^{-3}$. On the contrary, the lowest monthly concentrations were noted in soil solution sampled in February and March when DOC didn't exceed $50 \mathrm{mg}$ $\mathrm{C} \cdot \mathrm{dm}^{-3}$. This seasonal variation pointed to the existence of correlation between DOC concentration and soil temperature. Soil temperature at $30 \mathrm{~cm}$ of depth varied from 1.8 to $18.4^{\circ} \mathrm{C}$ during subsequent years.

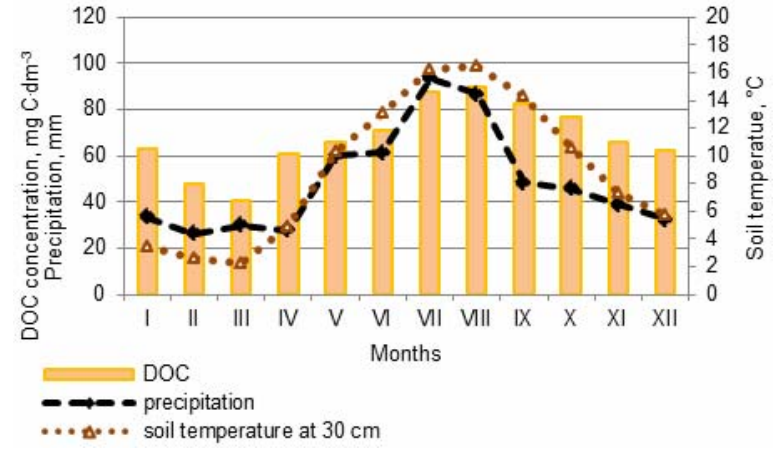

Fig. 2. Mean DOC concentration in soil solution in relation to mean monthly soil temperature and precipitation in the study period; source: own study

There was positive correlation between these two parameters $(r=0.50, n=115)$. Mean monthly DOC concentration in August (at highest soil temperature) was nearly twice higher than that in March at the lowest soil temperature.

Correlation between DOC concentration in soil solution and soil temperature found in this study raises a question: was the tendency in increasing DOC in subsequent years a result of air, soil or water temperature increment? Meteorological data of mean annual and seasonal (April-September) air temperature didn't indicate significant increase of this parameter during ten years involved (Fig. 3a). Mean air temperature didn't rise either in months in which the highest DOC concentration increment was noted (Fig. 3b). Moreover, worth noting is the fact that significant increment of DOC concentration for the whole study period took place in October in spite of relatively low air temperature in this month in 2009 and 2010.

On the contrary, mean soil temperature for vegetation period noted in 2007-2010 was a little higher in comparison to that from earlier years (Fig. 4a). Besides, in the second half of the study period, a significant increment of mean soil temperature was observed in June (Fig. 4b), which could enhance microbial activity in decomposition of soil organic material.

The results of this study suggest that soil temperature wasn't the only significant factor affecting the intensity of release and transport of DOC to soil solution in the study period. Summer increase of DOC could not also result from concentration of dissolved organic matter at poorer migration of rain water in soil profile since we observed the highest precipitation in this part of the year. Instead, an inverse phenomenon was possible: more intensive transport of DOC from muck layer to deeper soil levels with rain water in the period of production of new dissolved organic components.

The impact of groundwater table on DOC concentration in soil solution was ambiguous. There was no correlation between the two variables for the whole ten-year study period $(r=0.01, n=117)$. On the contrary, a significant increase of DOC concentration was observed in the years 2001-2009 at lower ground water tables $(r=0.47, n=111)$. No significant 

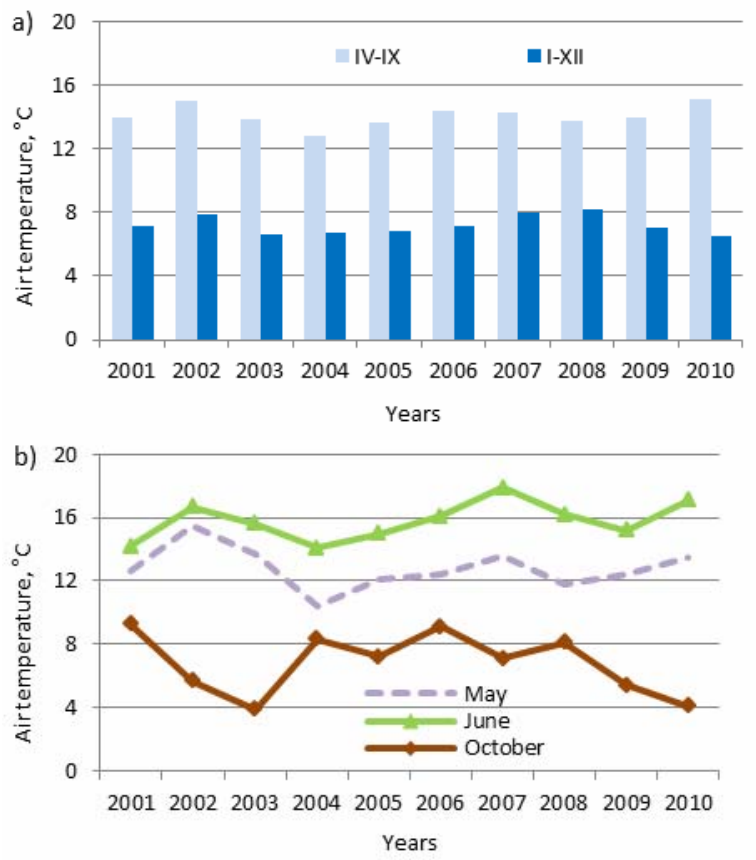

Fig. 3. Changes of mean air temperature: a) for the vegetation period (April-September) and for the whole year during 2001-2010; b) in months in which the largest increase of DOC concentration was observed; source: own study
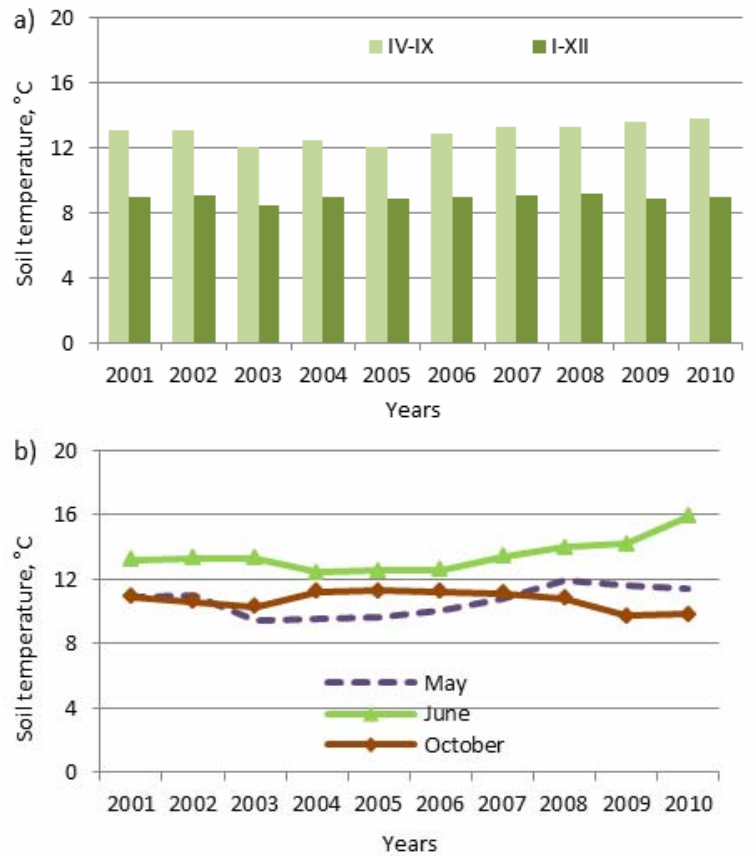

Fig. 4. Changes of mean soil temperature: a) for the vegetation period (April-September) and for the whole year during 2001-2010; b) in months in which the largest increase of DOC concentration was observed; source: own study

correlation was, however, found between DOC and soil moisture. This probably resulted from a huge water-holding capacity of these type of soil material, which retained a high moisture content even long after the decrease of groundwater table. Another parameter used to indirect characteristic of soil moisture is the redox potential. Its values point to relatively high aeration in analysed part of soil profile during a year, especially in 20-30 cm layer (Fig. 2). Highly significant positive correlation was found between DOC concentration in soil solution and redox potential in muck layer at 20 and $30 \mathrm{~cm}$ depth (Tab. 3). Despite a high variability of redox potential, this correlation evidence the dynamic transport of DOC from soil material to soil solution. One question is still unanswered: in what part the DOC concentration observed under described conditions resulted from higher mobility of organic compounds and in what part it followed from higher intensity of their formation?

Table 3. Redox potential in particular soil layers and correlation coefficients $r$ with DOC concentration in soil water from $30 \mathrm{~cm}$ depth (number of samples - 87)

\begin{tabular}{|c|c|c|c|c|}
\hline $\begin{array}{c}\text { Layer } \\
\mathrm{cm}\end{array}$ & Mean & Max & Min & $\begin{array}{c}\text { Correlation } \\
\text { coefficient } \\
\text { DOC-redox } r\end{array}$ \\
\hline 20 & 234 & 405 & -25 & $0.50^{* *}$ \\
\hline 30 & 307 & 405 & 24 & $0.23^{*}$ \\
\hline 40 & 171 & 361 & -266 & -0.12 \\
\hline
\end{tabular}

Explanations: $* *-$ significant at $\alpha>0.01 ; *-$ significant at $\alpha>$ 0.05 .

Source: own study.

DOC release to soil solution proceeded in a different way in 2010. Since May till October the highest concentrations of DOC were observed in particular samples at relatively high groundwater table (Fig. 1 and 5). That was why the correlation between DOC concentration and water level was disturbed for whole study period. The high groundwater table in 2010 was caused by relatively large precipitations in the study site (Fig. 5). This may suggest that much of DOC compounds (formed in preceding periods due to intensive mineralization at decreasing groundwater table and intensive aeration of upper part of the soil profile in 2008-2009) were released to soil solution under specific conditions associated with high groundwater table and plentiful rainfalls. Under such conditions, much of the rain water flows through the upper part of soil profile thus enhancing the intensity of migration of various DOC molecules.

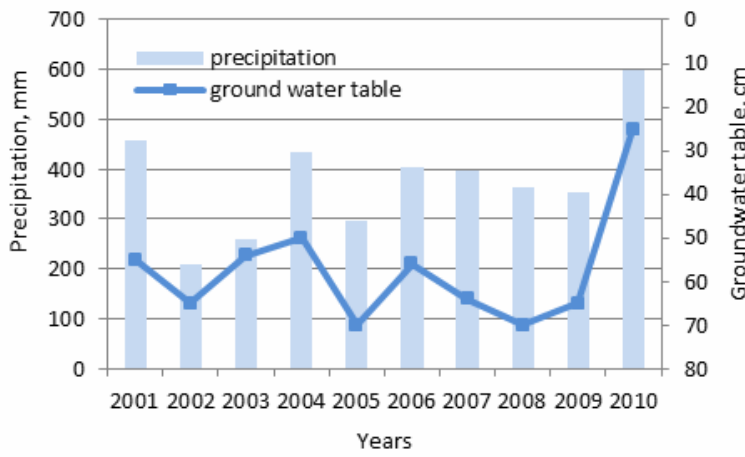

Fig. 5. Mean values* of precipitation and ground water table from April to November; * - mean values for period free from frozen soil and groundwater; source: own study 
INAMDAR et al. [2004] underlined a great role of storm events in DOC transport in the scale of whole catchments. JASZCZYŃSKI [2011] showed that DOC concentration in wells collecting ground water from organic layer of peat-muck soils was higher after large precipitation events. Significant increment of DOC concentration in ground water was often noted already 4-5 days after the occurrence of a downpour. In the present paper main attention was focused on DOC concentration in soil solution collected shortly after measuring abundant 24-hour rainfall. The threshold value was $30 \mathrm{~mm} \cdot$ day $^{-1}$. Such events were observed a few times in the whole study period. At the time DOC concentrations in soil solution always exceeded the mean concentration for the whole study period (Fig. 6). Rainfalls were particularly intensive in 2007 2010 i.e. in the period when the highest annual mean DOC concentrations were observed.

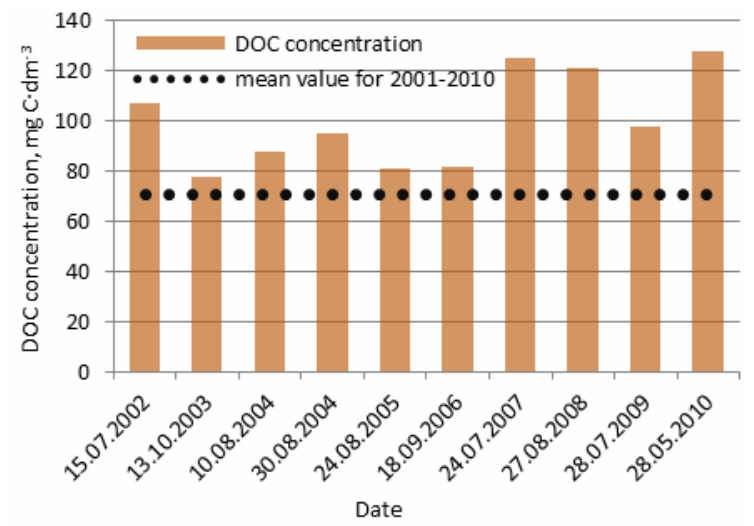

Fig. 6. DOC concentration in soil solution at $30 \mathrm{~cm}$ depth noted after* torrential rains characterised by 24 -hour rainfall above $30 \mathrm{~mm} ;{ }^{*}$ - samples of water collected from 3 to 15 days after storm events; source: own study

These abundant precipitations diluted soil solution but we didn't observe any reduction of DOC concentration under these conditions. This points to a large amount of DOC which was transported from muck layer to soil solution at $30 \mathrm{~cm}$ depth when rain water permeated down the soil profile.

Like DOC concentration, also the absorbance of soil solution at $280 \mathrm{~nm}$ showed clear tendency to increase in the whole study period (Fig. 7a). Organic compounds determined at this wavelength were mainly responsible for described tendency of increasing DOC concentration. The absorbance at $472 \mathrm{~nm}$ didn't show that trend (Fig. 7b). In the wet year 2010 (with the highest annual mean DOC concentration) the values of both absorbances increased in comparison with their means for earlier nine years by $61 \%$ and $100 \%$ for $\mathrm{A}_{280}$ and $\mathrm{A}_{472}$, respectively. So, the specific soil and water conditions observed in 2010 promoted stronger migration of organic compounds determined by $\mathrm{A}_{472}$ than those determined by $\mathrm{A}_{280}$ though the former are harder to migrate within the soil profile. It points that under varied soil conditions in studied sites the considerable reconstruction of the quality composition of organic compounds building DOC in soil

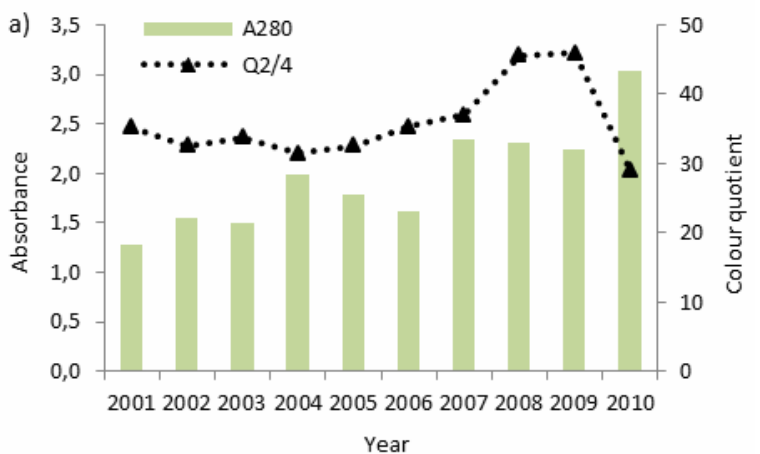

b)

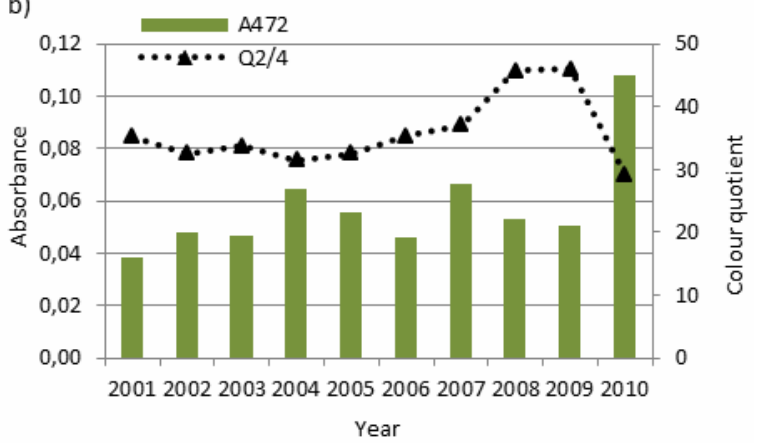

Fig. 7. Annual mean absorbance: a) at $280 \mathrm{~nm}$, b) at $472 \mathrm{~nm}$ and the colour quotient* in soil solution; * - calculated from absorbances of soil solution at $280 \mathrm{~nm}$ and $472 \mathrm{~nm}$ wavelengths; source: own study

solution was observed. These processes are visible in the colour quotient $\mathrm{Q}_{2 / 4}$ (Fig. 7).

Further studies are needed to precisely recognise the groups of organic compounds released from soil which we commonly name DOC. This is a prerequisite of complete understanding of chemical and physical mechanisms of their release and movement in soilwater medium.

\section{CONCLUSIONS}

1. Annual mean DOC concentration in soil solution from $30 \mathrm{~cm}$ depth of peat-muck soil (MtIIcb) showed the tendency to increase during decade (2001-2010) and increased twice in this time period. These results demonstrate alarming changes in organic matter loss from drained fens and show a real scale of threat for water resources.

2. The highest annual DOC concentration was observed in the year with the highest total precipitation and the greatest number of torrential rainfalls. This shows a great role of rain water for DOC transport from muck layer to soil solution. This observation is particularly important in view of climate changes manifested e.g. in increasing frequency of intensive storm rains.

3. Changes in the qualitative composition of compounds forming DOC were observed. The share of compounds determined at $280 \mathrm{~nm}$ increased in the study period. However, in years with large precipitations we could observe an intensive transport of compounds determined at $472 \mathrm{~nm}$. 


\section{REFERENCES}

Balla D., Dietrich O., Quasi J. 2000. Solute retention in a groundwater table controlled fen area with respect to various land use scenarios. International Peat Journal. Vol. 10 p. 33-47.

BANASZUK H. 2004. Geologia i geomorfologia Kotliny Biebrzańskiej. W: Kotlina Biebrzańska i Biebrzański Park Narodowy: aktualny stan, walory, zagrożenia i potrzeby czynnej ochrony środowiska. Monografia przyrodnicza [Geology and geomorphology of the Biebrza Valley. In: The Biebrza Valley and the Biebrza National Park. Biological monograph]. Ed. H. Banaszuk. Białystok. Wydaw. Ekon. Środ. p. 26-43.

Dawson J.J.C., Billett M.F., Neal C., Hill S. 2002. A comparison of particulate, dissolved and gaseous carbon in two contrasting upland streams in the UK. Journal of Hydrology. Vol. 257 p. 226-246.

GóRNIAK A. 1996. Substancje humusowe i ich rola w funkcjonowaniu ekosystemów słodkowodnych [Humic substances and their role in the functioning of freshwater ecosystems]. Warszawa. Wydaw. FUW. ISBN $838642351 X$ pp. 151.

INAMDAR S.P., CHRistopher S.F., Mitchell M.J. 2004. Export mechanisms for dissolved organic carbon and nitrate during summer storm events in a glaciated forested catchment in New York, USA. Hydrological Processes. Vol. 18. Iss. 14 p. 2651-2661.

JASZCZYŃSKI J. 2011. Rozpuszczalny węgiel organiczny w wodach siedlisk torfowych [Dissolved organic carbon in waters from peatlands]. Zeszyty Edukacyjne. $\mathrm{Nr} 13$. ISBN 978-83-62416-11-0 pp. 91.

JASZCZYŃSKi J., SAPEK A., CHRZANOWSKI S. 2008. Rozpuszczalny węgiel organiczny $\mathrm{w}$ wodzie $\mathrm{z}$ siedlisk pobagiennych na tle temperatury gleby [Dissolved organic carbon in water from post-bog habitats in comparison with soil temperature]. Woda-Srodowisko-Obszary Wiejskie. T. 8. Z. 1(22) p. 117-126.

KALBITZ K. 2001. Properties of organic matter in soil solution in a German fen area as dependent on land use and depth. Geoderma. Vol. 104. Iss. 3-4 p. 203-214.

Kalbitz K., Rupp H., Meissner R. 2002. N-, P- and DOC-dynamics in soil and groundwater after restoration of intensively cultivated fens. In: Wetlands in Central Europe. Eds. G. Broll, W. Merbach, E.-M. Pfeiffer. Berlin. Springer p. 99-116.

NADANY P., SAPEK A. 2004. Zróżnicowanie stężenia węgla organicznego w wodzie gruntowej w różnie użytkowanych glebach torfowych [Variability of organic carbon concentrations in ground water of differently used peat soils]. Woda-Środowisko-Obszary Wiejskie. T. 4. Z. 2 b(12) p. $281-289$.
OKRUSZKo H., KoZAKIEWICZ A. 1973. Humifikacja i mineralizacja jako elementy składowe procesu murszenia gleb torfowych [Humification and mineralization as components of peat soil mucking]. Zeszyty Problemowe Postępów Nauk Rolniczych. Z. 146 p. 63-76.

OKRUSZKO H., PIAŚCIK H. 1990. Charakterystyka gleb hydrogenicznych [Characteristics of hydrogenic soils]. Skrypt. Olsztyn. ART pp. 291.

QuINBY P.A. 2000. Lakes, wetlands and dissolved organic carbon in stream outlets of small northern temperate watersheds. Forest Landscape Baseline. No. 21 pp. 4.

Rupp H., KalBitz K., MEISSNER R. 2002. Impact of land use changes in the Drömling fen area on nutrient fluxes to the groundwater. In: Agricultural effects on ground and surface waters: research at the edge of science and society. Proceedings of an international symposium. Wageningen, Netherlands, October 2000. IAHS Publisher. No. 273 p. 261-265.

SAPEK A., SAPEK B., ChrZanowski S., JaszczyńSki J. 2007. Mobilization of substances in peat soils and their transfer within the groundwater and into surface water. Agronomy Research. Vol. 5. No. 2 p. 155-163.

SAPEK B., SAPEK A. 1999. Oznaczanie węgla organicznego w glebach łąkowych. W: Przewodnik metodyczny do badań materii organicznej gleb [Determination of organic carbon in meadow soils. In: Methodical guide for studying soil organic matter]. Eds. H. Dziadowiec, S. Gonet. Prace Komisji Naukowych PTG. Nr 120. Warszawa. PTG p. 5-57.

Skalar Flow Access 2002. User manual. Skalar Analytical $\mathrm{BV}$.

Smal H., Ligęza S., Misztal M. 2004. Quantity and quality of dissolved organic carbon in ground waters of agricultural catchment and in adjacent littoral waters of Piaseczno Lake. Annales UMCS. Sect. E. Agricultura. Vol. 59. No. 1 p. 423-430.

Szuniewicz J., ChrZanowski S. 1995. Przeobrażanie się i spłycanie odwodnionych gleb torfowych na przykładzie torfowiska Kuwasy. W: Torfoznawstwo w badaniach naukowych i praktyce [Transformation and shallowing of drained peat soils - an example of Kuwasy Peatland]. Materiały Seminaryjne. Nr 34. Falenty. Wydaw. IMUZ p. 241-246.

Tipping E., Woof C., Rigg E., Harrison A.F., InNESON P., TAylor K., Benham D., Poskitt J., Rowland A.P., BOL R., HARKNESS D.D. 1999. Climatic influences on the leaching of dissolved organic matter from upland UK moorland soils, investigated by a field manipulation experiment. Environment International. Vol. 25 Iss. 1 p. 83-95.

ZSOLNAY A. 1996. Dissolved humus in soil waters. In: Humic substances in terrestrial ecosystems. Ed. A. Piccolo. Amsterdam. Elsevier p. 171-223. 


\section{Jacek JASZCZYŃSKI}

Zależności między rozpuszczonym węglem organicznym a czynnikami hydro-klimatycznymi na przykladzie gleby torfowo-murszowej

\section{STRESZCZENIE}

Słowa kluczowe: gleby torfowo-murszowe, intensywne opady deszczu, potencjał elektryczny, roztwór glebowy, $R W O$, temperatura gleby

Przedmiotem badań było stężenie rozpuszczalnego węgla organicznego (RWO) w roztworze glebowym na tle poziomu wody gruntowej, temperatury i wilgotności gleby, jej potencjału elektrycznego oraz intensywnych opadów deszczu. Badania zlokalizowano na terenie zmeliorowanego i rolniczo użytkowanego Torfowiska Kuwasy, usytuowanego w środkowym basenie Biebrzy, w północno-wschodniej Polsce. Stanowisko badawcze zlokalizowano na glebie wytworzonej z torfów niskich (MtIIcb) użytkowanej jako intensywna łąka kośna. Stężenie RWO określono za pomocą kolorymetru przepływowego Skalar. Badania prowadzono w latach 2001-2010.

Średnie z całego okresu badawczego stężenie RWO w roztworze glebowym wyniosło $72 \mathrm{mg} \mathrm{C} \cdot \mathrm{dm}^{-3}$. Zaobserwowano istotną dodatnią korelację między stężeniem badanego składnika i temperaturą gleby na głębokości $30 \mathrm{~cm}$. Największe stężenie RWO występowało od lipca do października, kiedy to notowano również najniższy poziom zwierciadła wody gruntowej. Stężenie RWO wykazywało również istotną zależność od potencjału elektrycznego gleby notowanego na głębokości $20 \mathrm{~cm}$, gdzie występowała warstwa przejściowa torfu murszejącego, charakteryzująca się potencjalnie największą intensywnością przemian biochemicznych. Nie wykazano natomiast zależności między stężeniem RWO a wilgotnością górnych partii badanej gleby. Stwierdzono również istotne nasilenie przemieszczania się RWO z kompleksu glebowego do roztworu na skutek obfitych opadów deszczu. 